\title{
The effect of nutrients on carbon and nitrogen fixation by the UCYN-A-haptophyte symbiosis
}

\author{
Andreas Krupke ${ }^{1,3}$, Wiebke Mohr ${ }^{2,4}$, Julie LaRoche ${ }^{2,5}$, Bernhard M Fuchs ${ }^{1}$, Rudolf I Amann ${ }^{1}$ \\ and Marcel MM Kuypers ${ }^{1}$ \\ ${ }^{1}$ Max Planck Institute for Marine Microbiology, Bremen, Germany and ${ }^{2}$ Helmholtz-Zentrum für \\ Ozeanforschung, Kiel, Germany
}

\begin{abstract}
Symbiotic relationships between phytoplankton and $\mathrm{N}_{2}$-fixing microorganisms play a crucial role in marine ecosystems. The abundant and widespread unicellular cyanobacteria group A (UCYN-A) has recently been found to live symbiotically with a haptophyte. Here, we investigated the effect of nitrogen $(\mathrm{N})$, phosphorus $(\mathrm{P})$, iron $(\mathrm{Fe})$ and Saharan dust additions on nitrogen $\left(\mathrm{N}_{2}\right)$ fixation and primary production by the UCYN-A-haptophyte association in the subtropical eastern North Atlantic Ocean using nifH expression analysis and stable isotope incubations combined with single-cell measurements. $\mathrm{N}_{2}$ fixation by UCYN-A was stimulated by the addition of $\mathrm{Fe}$ and Saharan dust, although this was not reflected in the nifH expression. $\mathrm{CO}_{2}$ fixation by the haptophyte was stimulated by the addition of ammonium nitrate as well as $\mathrm{Fe}$ and Saharan dust. Intriguingly, the single-cell analysis using nanometer scale secondary ion mass spectrometry indicates that the increased $\mathrm{CO}_{2}$ fixation by the haptophyte in treatments without added fixed $\mathrm{N}$ is likely an indirect result of the positive effect of $\mathrm{Fe}$ and/or $\mathrm{P}$ on UCYN-A $\mathrm{N}_{2}$ fixation and the transfer of $\mathrm{N}_{2}$-derived $\mathrm{N}$ to the haptophyte. Our results reveal a direct linkage between the marine carbon and nitrogen cycles that is fuelled by the atmospheric deposition of dust. The comparison of single-cell rates suggests a tight coupling of nitrogen and carbon transfer that stays balanced even under changing nutrient regimes. However, it appears that the transfer of carbon from the haptophyte to UCYN-A requires a transfer of nitrogen from UCYN-A. This tight coupling indicates an obligate symbiosis of this globally important diazotrophic association.
\end{abstract}

The ISME Journal (2015) 9, 1635-1647; doi:10.1038/ismej.2014.253; published online 23 December 2014

\section{Introduction}

Open ocean environments are generally characterized by the scarcity of nutrients, particularly bioavailable (fixed) nitrogen $(\mathrm{N})$, that limits primary productivity (Karl et al., 2002). In such oligotrophic environments, the activity of diazotrophs, prokaryotic microorganisms that mediate the fixation of atmospheric $\mathrm{N}_{2}$ (Zehr et al., 1998; LaRoche and Breitbarth, 2005), is favored as they can overcome $\mathrm{N}$ limitation as long as other nutrients are not limiting. Since the 1960s, the most studied diazotroph has been the nonheterocystous, filamentous cyanobacterium Trichodesmium spp. that contributes significantly to $\mathrm{N}_{2}$ fixation in tropical and subtropical

Correspondence: A Krupke, Department of Marine Chemistry and Geochemistry, Woods Hole Oceanographic Institution, 360 Woods Hole Road, Fye 107C, Woods Hole, MA 02543, USA.

E-mail: akrupke@whoi.edu

${ }^{3}$ Current address: Department of Marine Chemistry and Geochemistry, Woods Hole Oceanographic Institution, Woods Hole, MA, USA.

${ }^{4}$ Current address: Max Planck Institute for Marine Microbiology, Bremen, Germany.

${ }^{5}$ Current address: Dalhousie University, Halifax, Nova Scotia, Canada.

Received 5 August 2014; revised 19 November 2014; accepted 24 November 2014; published online 23 December 2014 oceans (Capone et al., 2005). In addition, symbiotic relationships between diazotrophs and photosynthetic eukaryotes play a critical role in $\mathrm{N}_{2}$ fixation and carbon $(\mathrm{C})$ sequestration in the ocean (Carpenter and Foster, 2003, Karl et al., 2012). Foster et al. (2011) investigated various marine diazotrophdiatom symbiotic associations and showed that substantial amounts of fixed $\mathrm{N}$ are transferred from the diazotroph to the host, resulting into enhanced diatom growth rates.

More recently, the importance of $\mathrm{N}_{2}$-fixing unicellular cyanobacteria populations (UCYN-A, UCYN-B, UCYN-C) in the global N cycle has been recognized (Zehr et al., 2001; Montoya et al., 2004). Surveys based on quantitative PCR (qPCR) assays that target diazotroph abundance using the $\mathrm{N}_{2}$ fixation marker gene nifH (which encodes the monomer of the Fe-subunit protein of the nitrogenase, the key enzyme for $\mathrm{N}_{2}$ fixation) have revealed widespread distribution of the UCYN groups throughout the oceans (Church et al., 2005a; Langlois et al., 2008). The nifH gene phylotype abundances of UCYN-A (Candidatus Atelocyanobacterium thalassa; Thompson et al., 2012) can dominate diazotrophic communities (Luo et al., 2012) and can be found in more diverse environments than other diazotrophs (Short and Zehr, 2007; 
Rees et al., 2009; Moisander et al., 2010). Recently, UCYN-A has been found living in association with unicellular photosynthetic eukaryotes belonging to the Haptophyta, and more specifically, a prymnesiophyte (Thompson et al., 2012; Hagino et al., 2013; Krupke et al., 2013, 2014). It has been hypothesized that the eukaryotic photosynthetic partner provides C compounds for UCYN-A and, in return, obtains N compounds from UCYN-A (Thompson et al., 2012). Such an association seems mutually beneficial as the eukaryote cannot use $\mathrm{N}_{2}$ as an $\mathrm{N}$ source and, from what is known so far, UCYN-A lacks the capability to use $\mathrm{CO}_{2}$ as their $\mathrm{C}$ source (Zehr et al., 2008; Tripp et al., 2010; Thompson et al., 2014).

Unfortunately, cultures of UCYN-A do not exist, and field experiments are necessary to understand nutrient requirements and environmental parameters that regulate the physiological interactions between UCYN-A and their eukaryotic partner. For Trichodesmium and complex marine microbial communities, it has been shown that diazotrophic activity can be limited by phosphorus (P) or iron (Fe), or be co-limited by both (Sañudo-Wilhelmy et al., 2001; Mills et al., 2004; Shi et al., 2007), whereas eukaryotic phytoplankton are most often N limited. Currently, little is known about how UCYNA responds to nutrient limitation. A recent study investigating the response of nifH expression of different diazotrophs to nutrient additions indicated that UCYN-A might be $\mathrm{P}$ limited in the tropical North Atlantic (Turk-Kubo et al., 2012). To date, there are no reports on the effect of nutrient limitation on the photosynthetic partner of UCYN-A and/or this symbiosis.

Here, we conducted a wide range of nutrient amendment experiments near the Cape Verdean Islands to investigate the effect of nutrient additions on cellular $\mathrm{CO}_{2}$ and $\mathrm{N}_{2}$ fixation rates within the UCYN-A-haptophyte symbiosis. double catalyzed reporter deposition-fluorescence in situ hybridization (CARD-FISH) assays targeting UCYN-A cells, as well as their eukaryotic partner cells, allowed us to visualize the metabolic activity of UCYN-A at the single cell level using nanometer scale secondary ion mass spectrometry (nanoSIMS). In addition, we measured bulk $\mathrm{N}_{2}$ fixation activity and used qPCR to assess UCYN-A nifH gene and nifH transcript abundances. The results of this study will help to understand the physiology of this globally important diazotrophic symbiosis and how it might be influenced by changes in the environment.

\section{Materials and methods}

\section{Incubation experiments}

Surface sea water (5-10 m depth) was collected at night using trace metal clean techniques and a diaphragm pump near the Cape Verdean Islands $\left(16.79^{\circ} \mathrm{N}, 25.10^{\circ} \mathrm{W}\right)$ on board the $\mathrm{R} / \mathrm{V}$ Islandia in May 2009. Sea water was transferred into acid-cleaned $4.5 \mathrm{l}$ polycarbonate bottles and kept dark until further processing at the on-shore laboratory within $2-8 \mathrm{~h}$ of sampling. Incubation bottles were amended with nutrients, filled headspace free and closed with septa caps. Nutrient amendments resulted in 10 different treatments: (1) $\mathrm{Ctr}=$ control, no nutrients added, (2) $\mathrm{N}=\mathrm{NH}_{4} \mathrm{NO}_{3}$ (ammonium nitrate), (3) $\mathrm{Fe}=\mathrm{FeCl}_{3}$ (ferric chloride), (4) $\mathrm{P}=$ $\mathrm{NaH}_{2} \mathrm{PO}_{4}$ (monosodium phosphate), (5) $\mathrm{NP}=$ $\mathrm{NH}_{4} \mathrm{NO}_{3}+\mathrm{NaH}_{2} \mathrm{PO}_{4}$, (6) $\mathrm{NFe}=\mathrm{NH}_{4} \mathrm{NO}_{3}+\mathrm{FeCl}_{3}$, (7) $\mathrm{PFe}=\mathrm{NaH}_{2} \mathrm{PO}_{4}+\mathrm{FeCl}_{3}, \quad$ (8) $\quad \mathrm{NPFe}=\mathrm{NH}_{4} \mathrm{NO}_{3}+$ $\mathrm{NaH}_{2} \mathrm{PO}_{4}+\mathrm{FeCl}_{3}$, (9) $\mathrm{DI}=$ Saharan dust I and (10) $\mathrm{DII}=$ Saharan dust II (that is, $2 \times$ Saharan dust DI). Final concentrations were: $N(2 \mu \mathrm{M} \mathrm{N})$, Fe $(2 \mathrm{~nm}), \mathrm{P}$ $(0.2 \mu \mathrm{M})$, DI $\left(2 \mathrm{mg} \mathrm{l}^{-1}\right)$ and DII $\left(4 \mathrm{mg} \mathrm{l}^{-1}\right)$. The Saharan dust utilized in this study is the same as in Heller and Croot (2011), where the dust has been characterized in detail (that is, trace metal composition). Each treatment was prepared in quadruplicate.

All incubation bottles were placed in an incubator with continuously flowing surface sea water $\left( \pm 3{ }^{\circ} \mathrm{C}\right.$ in situ temperature) and shaded to $25 \%$ surface irradiance (blue lagoon, 172 Lee Filters, Seattle, WA, USA). After $24 \mathrm{~h}$ of incubation, three bottles were amended with $2.2 \mathrm{ml}{ }^{15} \mathrm{~N}_{2}$ per $\mathrm{l}\left(98 \%+{ }^{15} \mathrm{~N}_{2}\right.$, Sigma-Aldrich, St Louis, MO, USA) and $240 \mu \mathrm{M}$ ${ }^{13} \mathrm{C}$ bicarbonate solution $\left(\mathrm{H}^{13} \mathrm{CO}_{3}^{-}\right)\left(98 \%+{ }^{13} \mathrm{CO}_{2}\right.$, Silantes, Munich, Germany) using gas-tight syringes. The fourth bottle was amended with unlabeled bicarbonate solution and air to determine background natural abundance of ${ }^{13} \mathrm{C}$ and ${ }^{15} \mathrm{~N}$. All bottles were incubated for a second 24 -h period.

\section{Isotope ratio mass spectrometry}

Experiments were stopped by filtering 2-3l of sea water from the incubations onto pre-combusted $\left(450^{\circ} \mathrm{C}, 6 \mathrm{~h}\right) 25 \mathrm{~mm} \mathrm{GF} / \mathrm{F}$ filters (Whatman, St Louis, MO, USA). Filters were acidified with fuming $\mathrm{HCl}$ in a desiccator overnight, oven dried for $1 \mathrm{~h}$ at $55{ }^{\circ} \mathrm{C}$ and pelletized in tin cups. Particulate organic $\mathrm{C}$ and $\mathrm{N}$ and the relative abundances of ${ }^{13} \mathrm{C}$ and ${ }^{15} \mathrm{~N}$ were determined through continuous flow isotope ratio mass spectrometry coupled to an elemental analyzer. Bulk $\mathrm{N}_{2}$ fixation rates were then calculated following Montoya et al. (1996).

\section{Nucleic acid extraction}

Subsamples for DNA and RNA (1.5-2 l) were taken from each bottle that was amended with ${ }^{13} \mathrm{C}$ bicarbonate and ${ }^{15} \mathrm{~N}_{2}$ gas (that is, triplicate samples) and filtered onto $47 \mathrm{~mm}$ Durapore $(0.2 \mu \mathrm{M}$ pore size; Millipore, Darmstadt, Germany) filters and stored at $-80^{\circ} \mathrm{C}$. Nucleic acids were extracted with the Qiagen (Hilden, Germany) DNA/RNA Plant Mini kit. Samples were prepared for extraction following Langlois et al. (2012). To facilitate cell lysis, $200 \mu \mathrm{l}$ of lysozyme solution $\left(5 \mathrm{mg} \mathrm{ml}^{-1}\right.$ in $\mathrm{TE}$ buffer) was added initially into vials, vortexed, incubated at room temperature for $5 \mathrm{~min}$ and then the manufacturer's protocol was followed. DNA was eluted in $2 \times 30 \mu \mathrm{l}$ of TE buffer; RNA was eluted in $1 \times 50 \mu \mathrm{l}$ of 
DEPC-treated water. DNA and RNA were stored at $-80^{\circ} \mathrm{C}$ until further analysis.

Reverse transcription-qPCR (RT-qPCR)

Eluted RNA was treated with Ambion's (Waltham, MA, USA) Turbo DNA-free kit to remove residual genomic DNA and reverse transcribed (RT) using the Super-Script III cDNA synthesis kit (Invitrogen, Karlsruhe, Germany) and the general nifH2 (Zehr and McReynolds, 1989) and nifH3 primers (Zani et al., 2000). No RT controls were later used from randomly selected samples to confirm the absence of genomic DNA in RT-qPCR.

Quantitative PCR (qPCR and RT-qPCR) and TaqMan Technology (St Louis, MO, USA) (including primer and probe sequences) were used according to Langlois et al. (2008) to determine the nifH abundance and the nifH gene expression levels of UCYNA using the extracted DNA and the synthesized cDNA, respectively.

\section{Double CARD-FISH assay}

Aliquots $(20 \mathrm{ml})$ of each incubation bottle were preserved in $1 \%$ paraformaldehyde for $24 \mathrm{~h}$ at $4{ }^{\circ} \mathrm{C}$. Aliquots were filtered onto gold/palladium pre-sputtered $25 \mathrm{~mm}$ polycarbonate GTTP filters $(0.2 \mu \mathrm{M}$ pore size; Millipore), washed with $0.2 \mu \mathrm{M}$ filtered sea water and stored at $-20^{\circ} \mathrm{C}$.

Phylogenetic identification was performed through two separate rounds of CARD-FISH. First, we used the $18 \mathrm{~S}$ rRNA oligonucleotide probe PRYM02 (5'-GGAATACGAGTGCCCCTGAC- $\left.3^{\prime}\right)$ in combination with Alexa594 tyramides (Molecular Probes, Leiden, The Netherlands) targeting Haptophyta (Simon et al., 2000) and following standard protocols (Pernthaler and Amann, 2004; Pernthaler et al., 2004). After completing the first round of CARD-FISH, filter sections were washed in $1 \times$ phosphate-buffered saline for 10-20 min in the dark and placed in $3 \% \mathrm{H}_{2} \mathrm{O}_{2}$ solution for $20 \mathrm{~min}$ at room temperature in order to inactivate the inserted horseradish peroxidase and to prepare filter sections for the second CARD-FISH. Here, the oligonucleotide probe UCYN-A732 (5'-GTTACGGTCCAGTAG CAC-3'), which targeted the $16 \mathrm{~S}$ rRNA specific for UCYN-A cells, and its corresponding helper probes Helper A-732 and Helper B-732 (5'-GCCTTCGCCAC CGATGTTCTT-3' ${ }^{\prime}$ and $5^{\prime}$-AGCTTTCGTCCCTGAGTG TCA-3') were applied to increase the probes' access to $16 \mathrm{~S}$ rRNA target regions according to Krupke et al. (2013). During the second CARD-FISH application, fluorine $\left({ }^{19} \mathrm{~F}\right)$-labeled tyramides were used (that is, Oregon Green 488, Molecular Probes). Lastly, the cells were counterstained with $1 \mu \mathrm{g} \mathrm{ml}^{-1}$ DAPI (4',6-diamidino-2-phenylindol) for $10 \mathrm{~min}$ at room temperature in the dark.

The horseradish peroxidase-labeled oligonucleotide probes were used at working solutions of $8.42 \mathrm{pmol}_{\mu} \mathrm{l}^{-1}$, following dilution of stock solutions in the hybridization buffer (1:300; v-v).
All hybridizations were performed at optimal formamide concentrations to ensure maximal stringency (Krupke et al., 2013); the oligonucleotides EUB338 (Amann et al., 1990) or EUK516 (Amann et al., 1990) were used as positive controls and the oligonucleotide NON338 (Wallner et al., 1993) was used as a negative control.

Marking, microscopy and mapping for nanoSIMS Laser markings were made near positively hybridized UCYN-A-haptophyte cells via a Laser Microdissection Microscope 6500 (Leica, Solms, Germany). Optical filter sets suitable for the applied tyramides during the CARD-FISH assays were used. Filter pieces were examined and microscopic pictures taken using a Zeiss Axioskop II fluorescence microscope (Zeiss, Oberkochen, Germany). Pictures were used for orientation during subsequent nanoSIMS analysis. Filter pieces were washed and air-dried before nanoSIMS analysis.

\section{NanoSIMS measurements}

Single-cell isotope ratios were measured and visualized using a Cameca NanoSIMS 50L instrument (Cameca, Gennevilliers, France). Before analysis, the area was pre-sputtered for 1-2 min with a defocused positively charged Cesium $\left(\mathrm{Cs}^{+}\right)$primary ion beam to implant $\mathrm{Cs}^{+}$on the sample surface and get a sputter equilibrium. Then, sample surfaces were rastered with a $16 \mathrm{keV} \mathrm{Cs}^{+}$beam and a current between 1 and 3 pA. Primary ions were focused into a nominal $\sim 100 \mathrm{~nm}$ spot diameter. The primary ion beam was used to raster the analyzed area with an image size of $256 \times 256$ pixels and a dwelling time of 1 or $3 \mathrm{~ms}$ per pixel. Raster areas were usually $10 \times 10 \mu \mathrm{M}$. Negatively charged secondary ions of carbon (C), fluorine (F), nitrogen (as $\mathrm{CN}$ ) and sulfur (S) (that is, ${ }^{12} \mathrm{C}^{-},{ }^{13} \mathrm{C}^{-},{ }^{19} \mathrm{~F}^{-},{ }^{12} \mathrm{C}^{14} \mathrm{~N}^{-},{ }^{12} \mathrm{C}^{15} \mathrm{~N}^{-}$and ${ }^{32} \mathrm{~S}^{-}$) were measured simultaneously in raster imaging mode by electron multiplier detectors.

All scans (40-50 planes) were corrected for drift of the beam and sample stage after acquisition. Isotope ratio images were created as the ratio of a sum of total counts for each pixel over all recorded planes with respect to the investigated isotope. Regions of interest around cell structures were circled and calculated using the automated threshold feature based on the look@nanosims software (Polerecky et al., 2012). Cell dimensions were determined based on regions of interest.

\section{Calculations}

$\mathrm{CO}_{2}$ and $\mathrm{N}_{2}$ fixation rates (including $\mathrm{C}$ and $\mathrm{N}$ transfer rates) for individual cells were calculated using the equations listed below. The biovolume ( $V$ ) was calculated from individual cell diameters and assuming a spherical shape for both UCYN-A and the haptophyte that had been confirmed 
microscopically. The $\mathrm{C}$ content per individual UCYN-A cell was determined according to Verity et al. (1992):

$$
\log [\mathrm{C}]=-0.363+(0.863 \times(\log (\mathrm{V}))
$$

Estimates of $\mathrm{C}$ content per individual haptophyte cell were according to Strathmann (1967):

$$
\log [\mathrm{C}]=-0.422+(0.758 \times(\log (\mathrm{V}))
$$

The $\mathrm{C}$ content per cell $\left(\mathrm{C}_{\text {con }}\right)$ was converted into $\mathrm{N}$ content per cell $\left(\mathrm{N}_{\text {con }}\right)$ based on conversion factors provided by Tuit et al. (2004) assuming a modified Redfield ratio $(\mathrm{C} / \mathrm{N})$ of 8.6. The isotopic ratios $\left(R_{\mathrm{C}}={ }^{13} \mathrm{C} /{ }^{12} \mathrm{C}\right.$ and $\left.\mathrm{R}_{\mathrm{N}}={ }^{15} \mathrm{~N} /{ }^{14} \mathrm{~N}\right)$ based on region of interest selections and nanoSIMS analysis were used to calculate atom percent (AT\%) enrichment of ${ }^{13} \mathrm{C}$ or ${ }^{15} \mathrm{~N}$ by:

$$
\begin{aligned}
& A_{C}=R_{C} /\left(R_{C}+1\right) \\
& A_{N}=R_{N} /\left(R_{N}+1\right)
\end{aligned}
$$

where $A_{\mathrm{C}}$ represents AT\% enrichment of ${ }^{13} \mathrm{C}$ and $A_{\mathrm{N}}$ represents the $\mathrm{AT} \%$ enrichment of ${ }^{15} \mathrm{~N}$. The cellspecific $\mathrm{C}$ and $\mathrm{N}$ fixation $\left(\mathrm{F}_{\mathrm{C}}\right.$ or $\left.\mathrm{F}_{\mathrm{N}}\right)$ were calculated according to the length of incubation time after stable isotope amendments (that is, $24 \mathrm{~h}$ ) with:

$$
\begin{gathered}
\mathrm{F}_{\mathrm{C}}=\left({ }^{13} \mathrm{C}_{\mathrm{ex}} / \mathrm{C}_{\mathrm{SR}}\right) \times \mathrm{C}_{\mathrm{con}} \\
\mathrm{F}_{\mathrm{N}}=\left({ }^{15} \mathrm{~N}_{\mathrm{ex}} / \mathrm{N}_{\mathrm{SR}}\right) \times \mathrm{N}_{\mathrm{con}}
\end{gathered}
$$

where ${ }^{13} \mathrm{C}_{\text {ex }}$ and ${ }^{15} \mathrm{~N}_{\text {ex }}$ represent the AT\% enrichment of ${ }^{13} \mathrm{C}$ and ${ }^{15} \mathrm{~N}$ of the individual regions of interest corrected for the mean AT\% ${ }^{13} \mathrm{C}$ and $\mathrm{AT} \%{ }^{15} \mathrm{~N}$ at time 0 , that is, ${ }^{13} \mathrm{C}$ and ${ }^{15} \mathrm{~N}$ excess. The $\mathrm{AT} \%$ enrichment of ${ }^{13} \mathrm{C}$ and ${ }^{15} \mathrm{~N}$ at time 0 were determined on bulk samples using elemental analyzer-isotope ratio mass spectrometry. The elemental analyzerisotope ratio mass spectrometry was calibrated for nonenriched and enriched samples with high instrument accuracy and precision (for example, $0.3651 \pm 0.0000{ }^{15} \mathrm{~N}$ atom $\%$ and $1.0658 \pm 0.0004{ }^{13} \mathrm{C}$ atom \% based on the mean and s.d. of caffeine standards. The AT\% labeling of $\mathrm{C}\left(\mathrm{C}_{\mathrm{SR}}\right)$ and $\mathrm{N}\left(\mathrm{N}_{\mathrm{SR}}\right)$ substrates in the experimental bottle, that is, $\mathrm{CO}_{2}$ and $\mathrm{N}_{2}$, was calculated and corrected for the natural abundance of ${ }^{13} \mathrm{C}$ and ${ }^{15} \mathrm{~N}$. This study presents measured AT\% ${ }^{13} \mathrm{C}$ and $\mathrm{AT} \%{ }^{15} \mathrm{~N}$ enrichment values of individual cells and utilizes these data to calculate single-cell $\mathrm{CO}_{2}$ and $\mathrm{N}_{2}$ fixation rates.

\section{Statistical evaluations}

Bulk $\mathrm{N}_{2}$ fixation rates, nifH gene and nifH transcript abundances, and single-cell $\mathrm{CO}_{2}$ and $\mathrm{N}_{2}$ fixation results (including AT\% ${ }^{13} \mathrm{C}$ and ${ }^{15} \mathrm{~N}$ enrichment values) were statistically evaluated using SigmaStat 3.5 software (Systat Software Inc., San Jose, CA, USA). The equal variance within each treatment was first tested to proceed with a regular $t$-test for comparison between the control and each individual treatment (significance at $P<0.05$ ). In instances where a nonnormal distribution was detected, we applied the Mann-Whitney rank-sum test.

\section{Results}

Bulk $\mathrm{N}_{2}$ fixation rates and nifH gene and nifH transcript abundance of UCYN-A

Bulk $\mathrm{N}_{2}$ fixation activity across all nutrient treatments varied between $0.8 \pm 0.1$ and $1.3 \pm 0.6 \mathrm{nmol} \mathrm{l}^{-1}$ $\mathrm{N}$ per day and did not differ significantly from the control $\left(1.0 \pm 0.2 \mathrm{nmoll}^{-1} \mathrm{~N}\right.$ per day; $P>0.05$; Figure 1a). The nifH phylotype UCYN-A was detected by qPCR in all nutrient treatment incubation experiments at moderate abundances $\left(10^{3}-10^{4}\right.$ nifH gene copies per l; Figure 1b), but no significant differences between any two treatments were observed $(P>0.05)$. The UCYN-A nifH transcript abundances were approximately one order of magnitude higher than nifH gene copies across all treatments (Figure 1b). The ratio of nifH transcript to nifH gene abundance is within the range previously reported for UCYN-A (Church et al., 2005b; Turk-Kubo et al., 2012). Overall, nifH transcript abundances did not differ significantly between any two treatments $(P>0.05)$.
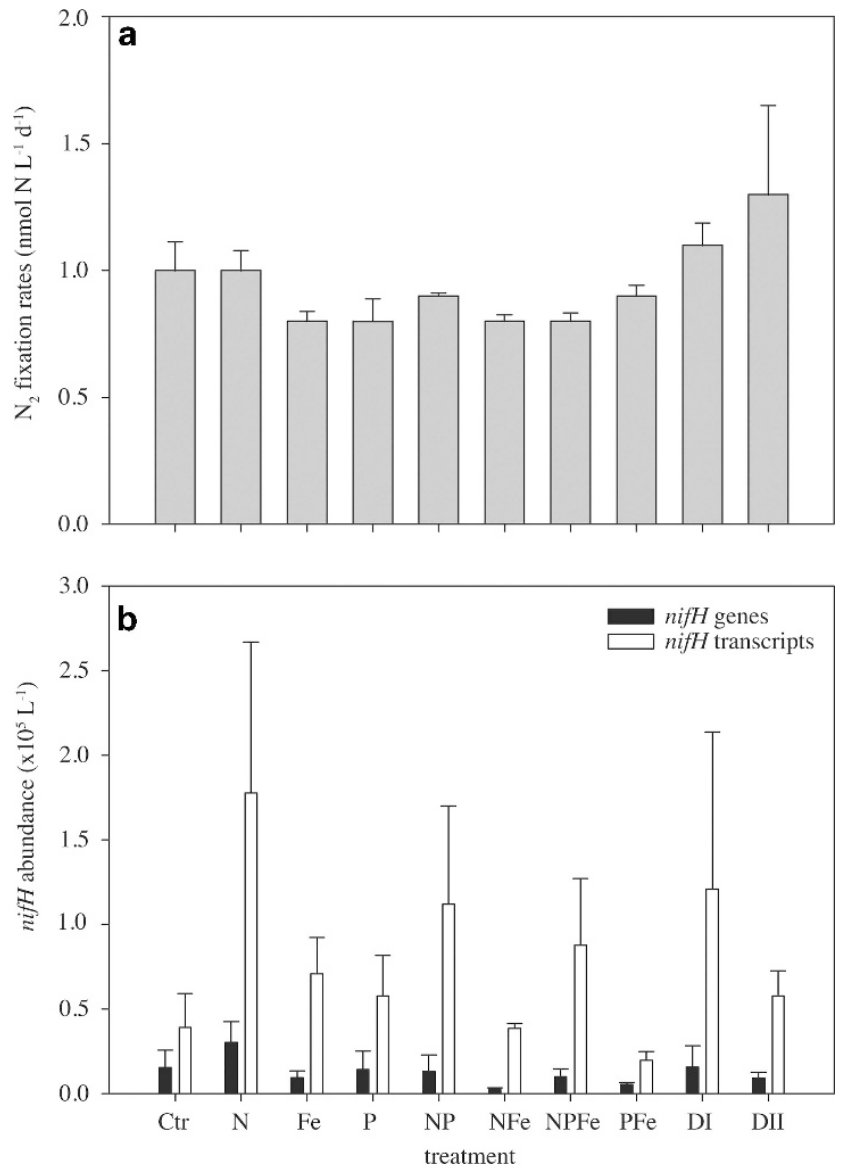

Figure 1 Mean bulk $\mathrm{N}_{2}$ fixation rates (a), as well as mean UCYNA nifH gene and nifH transcript abundance (b) with s.e. from incubation experiments across nutrient treatments as described in the Materials and Methods. 
Visualization of UCYN-A-haptophyte associations UCYN-A cells and partner haptophyte cells were simultaneously identified via the double CARDFISH approach (Figures 2a, d and g, small inserts). The application of the UCYN-A-specific oligonucleotide probe (Krupke et al., 2013) in concert with the deposition of halogenated $\left({ }^{19} \mathrm{~F}\right)$ tyramides allowed us to verify the phylogenetic identification of UCYN-A cells and to image single-cell $\mathrm{N}_{2}$ and $\mathrm{CO}_{2}$ fixation within UCYN-A-haptophyte associations via nanoSIMS measurements (Figures 2a-i). Examples for individual associations in the control, $\mathrm{N}$ and Saharan dust DII treatments are shown in Figures 2a-i.
NanoSIMS measurements of all examined cells across all treatments gave average cell diameters and associated s.d. values of $0.83 \pm 0.15 \mu \mathrm{M}$ for UCYN-A ( $n=44$ cells) and $1.66 \pm 0.23 \mu \mathrm{M}$ for haptophyte cells ( $n=44$ cells). Biovolumes were calculated based on individual cell diameter following the termination of each treatment (Figures 3a and b and Supplementary Figures 1A-D). Overall, average biovolumes and associated s.d. values of UCYN-A cells across treatments $\left(0.33 \pm 0.17 \mu \mathrm{m}^{3} ; n=36\right)$ were not significantly different from the unamended control $\left(0.27 \pm 0.08 \mu \mathrm{m}^{3} ; n=8 ; P>0.05\right)$.

In contrast to the UCYN-A, nutrient additions led to increased biovolumes of haptophyte cells. Except
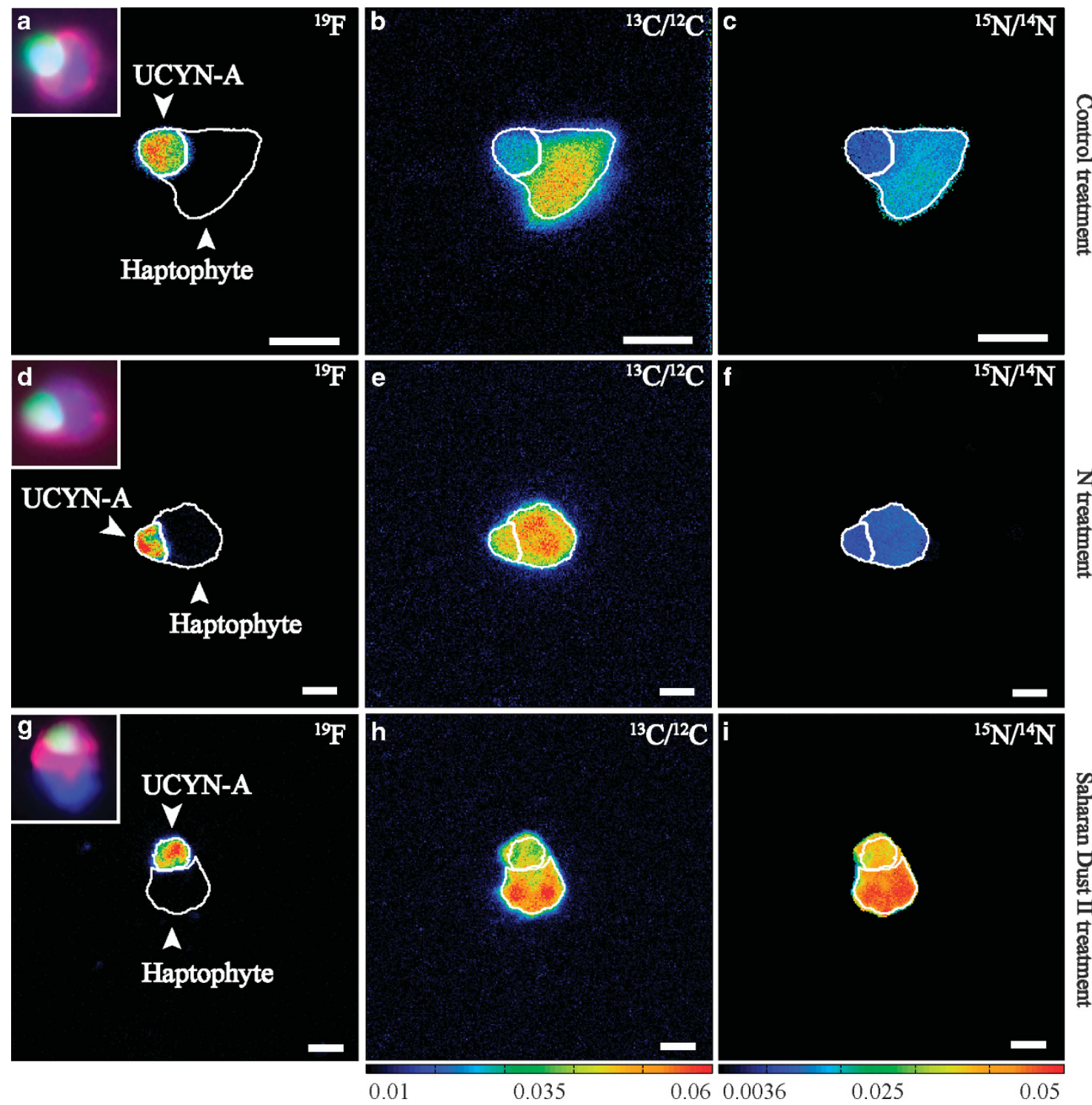

Figure 2 Visualization of the UCYN-A-haptophyte association according to the probe-conferred ${ }^{19} \mathrm{~F}$ signal (left panels a, d, g) and single-cell activities based on isotope ratios of $\mathrm{C}\left({ }^{13} \mathrm{C} /{ }^{12} \mathrm{C}=\right.$ middle panels $\left.\mathbf{b}, \mathbf{e}, \mathbf{h}\right)$ and $\mathrm{N}\left({ }^{15} \mathrm{~N} /{ }^{14} \mathrm{~N}=\right.$ right panels $\mathbf{c}, \mathbf{f}$, i) within different nutrient amendment incubation experiments. Inset panels on the left side show the corresponding epifluorescence images of the UCYNA cells (green signal) and its associated haptophyte cell (red signal), as well as DAPI staining (blue signal) based on double CARD-FISH approach taken before nanoSIMS analysis. NanoSIMS images refer to different nutrient amendment incubation experiments: (a-c) Control $=$ no nutrient added, (d-f) $\mathrm{N}=\mathrm{NH}_{4} \mathrm{NO}_{3}$ addition, (g-i) DII $=4 \mathrm{mg} \mathrm{l}^{-1}$ Saharan dust. Warmer colors represent higher abundance of the heavier isotopes. 


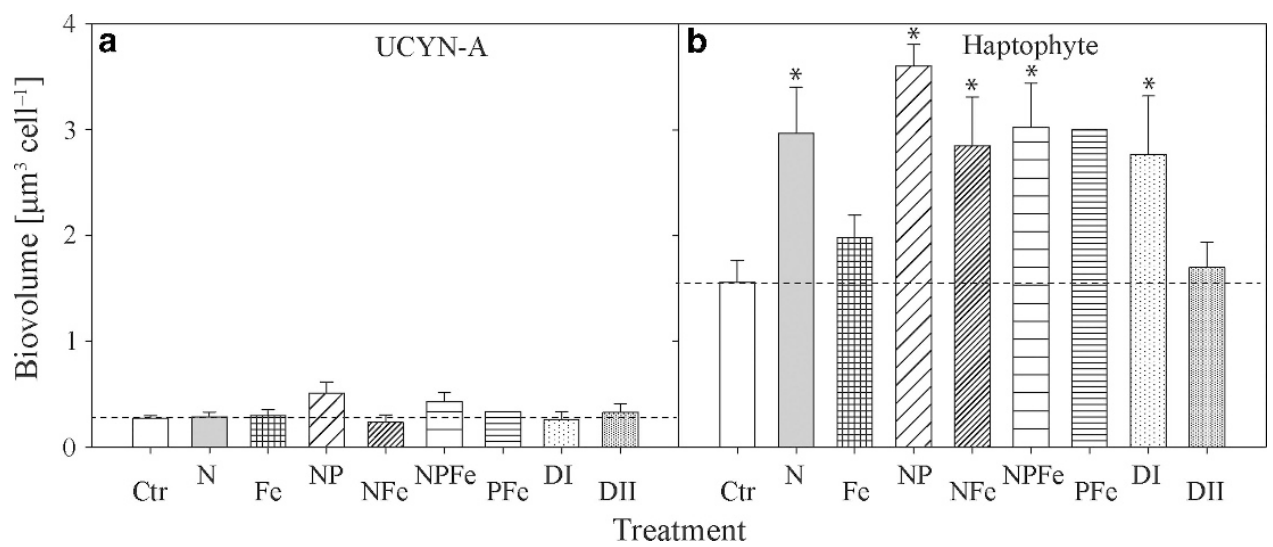

Figure 3 Mean biovolumes with s.e. for (a) UCYN-A and (b) the associated haptophyte cells in the different treatments as described in the Materials and Methods. The asterisks indicate a statistically significant difference compared with the control. No statistics were performed on results from the PFe treatment because only one UCYN-A-haptophyte association was found. Dashed lines indicate mean values of control measurements.

for the Fe and Saharan dust DII treatments, calculated biovolumes in the nutrient treatments were significantly larger $\left(3.05 \pm 0.16 \mu \mathrm{m}^{3} ; n=27\right)$ than the control $\left(1.56 \pm 0.21 \mu \mathrm{m}^{3} ; n=8 ; P<0.05\right.$; Figure $3 \mathrm{~b})$. The largest biovolume was observed in the NP treatment $\left(3.60 \pm 0.20 \mu \mathrm{m}^{3}\right)$. Generally, estimated biovolumes for associated haptophyte cells were $\sim 3-10$ times larger than values for UCYN-A cells (Figures 3a and b).

\section{Inorganic carbon fixation in haptophyte cells and} transfer to UCYN-A cells

All investigated cells were enriched in ${ }^{13} \mathrm{C}$, indicating inorganic $\mathrm{C}$ fixation by these symbioses (Figures $4 \mathrm{a}-\mathrm{d}$ and Supplementary Figures $2 \mathrm{~A}$ and B). The actual $\mathrm{CO}_{2}$ fixation might be even higher; a recent study by Musat et al. (2014) revealed that the application of FISH and CARD-FISH techniques before nanoSIMS measurements can lower cellular ${ }^{13} \mathrm{C}$ and ${ }^{15} \mathrm{~N}$ enrichments, leading to the underestimation of rates. As UCYN-A does not have any genes for $\mathrm{CO}_{2}$ fixation, we regard any ${ }^{13} \mathrm{C}$ enrichment as originating from $\mathrm{CO}_{2}$-derived $\mathrm{C}$ transfer from the host.

The ${ }^{13} \mathrm{C}$ enrichments of haptophyte cells were not significantly different between treatments $(P>0.05$; Figure 4c and Supplementary Table 1). In comparison, the ${ }^{13} \mathrm{C}$ enrichment in UCYN-A cells was significantly elevated in the following treatments: (1) Fe, (2) NP, (3) NPFe and (4) Saharan dust DII $(P<0.05$; Table 1 and Figure 4a). Across treatments, ${ }^{13} \mathrm{C}$ enrichments in haptophyte cells were up to twice as high as the ${ }^{13} \mathrm{C}$ enrichment of their respective UCYN-A symbiont (Figures 4a and c and Supplementary Figures 3A-I).

Estimated $\mathrm{CO}_{2}$ fixation rates in haptophyte cells increased significantly in all nutrient treatments compared with the control $(P<0.05)$, except in the Saharan dust DII treatment (Table 1 and Figure 4d). $\mathrm{CO}_{2}$ fixation rates by haptophytes were up to seven times greater than the transfer rates of the fixed $\mathrm{C}$ to
UCYN-A (Table 1 and Figures $4 \mathrm{~b}$ and $d$ ). The calculated $\mathrm{CO}_{2}$-derived $\mathrm{C}$ transfer rates among UCYN-A cells were up to 3 times higher after nutrient addition than in the control treatment and differed significantly from the control in the $\mathrm{Fe}, \mathrm{NP}$ and the NPFe treatments $(P<0.05$; Table 1 and Figure $4 \mathrm{~b})$. Elevated $\mathrm{CO}_{2}$-derived $\mathrm{C}$ transfer to UCYN-A was also observed in the $\mathrm{PFe}$ treatment, but the available data set for this treatment is limited because only one symbiosis could be found. No data are available from the P-only treatment because no double-hybridized UCYN-A-haptophyte associations were found in the investigated sample. Overall, a strong correlation in the ${ }^{13} \mathrm{C}$ enrichment $(r=0.79)$ as well as in the $\mathrm{CO}_{2}$ fixation rates $(r=0.60)$ between UCYN-A and haptophyte cells were detected across all treatments (Figures $5 \mathrm{a}$ and $\mathrm{b}$ ).

\section{Nitrogen fixation in UCYN-A and transfer of nitrogen} to associated haptophyte cells

In contrast to UCYN-A, which lacks the ability to fix $\mathrm{CO}_{2}$ but can fix $\mathrm{N}_{2}$, the haptophyte cannot perform $\mathrm{N}_{2}$ fixation; thus, we regard any ${ }^{15} \mathrm{~N}$ enrichment in the haptophyte as $\mathrm{N}_{2}$-derived $\mathrm{N}$ transfer from UCYN-A. Within each treatment, the ${ }^{15} \mathrm{~N}$ enrichment between individual UCYN-A cells and their respective haptophyte host showed similar patterns (Figures 4e and g and Supplementary Figures 3A-I). Nonetheless, the ${ }^{15} \mathrm{~N}$ enrichment and $\mathrm{N}_{2}$-derived $\mathrm{N}$ transfer rates among individual haptophyte cells, as well as individual UCYN-A cells, differed significantly between treatments (Figures $4 \mathrm{e}-\mathrm{h}$ ). In particular, UCYN-A cells were significantly enriched in ${ }^{15} \mathrm{~N}(2-3$-fold) in the iron and Saharan dust (Fe, DI, DII) additions compared with the control $(P<0.05$; Figure 4e). This resulted in corresponding $\mathrm{N}_{2}$ fixation rates for UCYN-A cells that were significantly higher in the Fe, Saharan dust DI and DII treatments than in the control $(P<0.05$; Table 1 and Figure 4f). $\mathrm{N}_{2}$ fixation rates were not significantly different from the control when inorganic $\mathrm{N}$ (that is, 


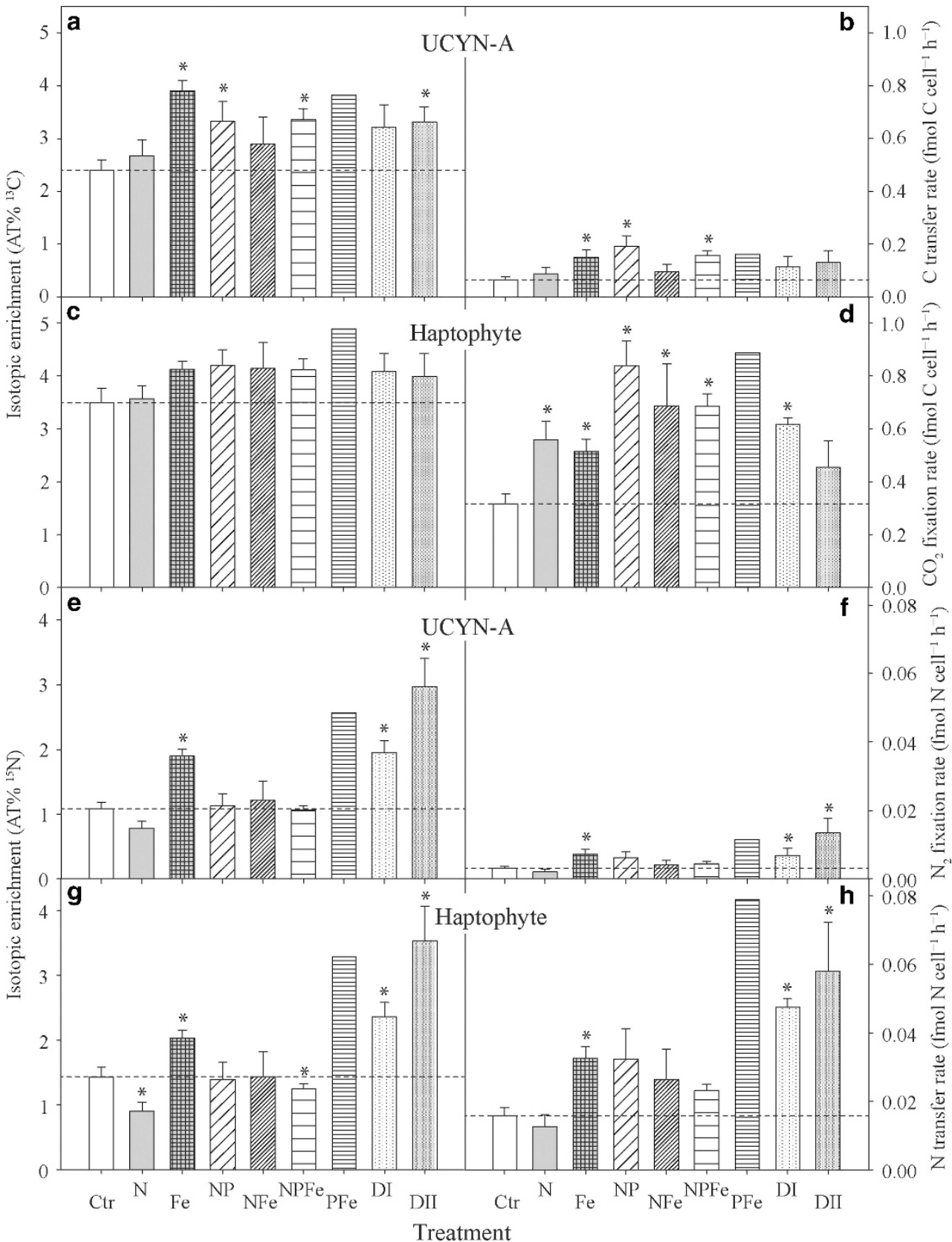

Figure 4 NanoSIMS measurements for the association between UCYN-A and their associated haptophytes from the nutrient amendment experiments. The panels on the left side represent the isotope enrichment in $\mathrm{AT} \%$ for individual cells for ${ }^{13} \mathrm{C}$ (a, UCYN-A; c, haptophyte) and ${ }^{15} \mathrm{~N}$ (e, UCYN-A; g, haptophyte). The panels on the right side (b, d, f, h) show the corresponding single-cell activity in fmol cell ${ }^{-1} \mathrm{~h}^{-1}$ for $\mathrm{CO}_{2}$ and $\mathrm{N}_{2}$ fixation, as well as $\mathrm{C}$ and $\mathrm{N}$ transfer rates for individual UCYN-A and partner haptophyte cells, calculated based on obtained nanoSIMS values (AT\%) and cell dimension analysis. Treatments are as described in Materials and Methods. The asterisk symbol indicates means that are significantly different from the control at a $P<0.05$ significance level. No statistics were performed on the PFe treatment. Dashed lines indicate mean values of control measurements.

$\mathrm{NH}_{4} \mathrm{NO}_{3}$ ) was available (Table 1 and Figure $4 \mathrm{f}$ ), that is, $\mathrm{N}_{2}$ fixation was not inhibited by the presence of fixed $\mathrm{N}$.

The ${ }^{15} \mathrm{~N}$ enrichment in haptophyte cells was significantly enhanced (2-3-fold) following $\mathrm{Fe}$ and Saharan dust DI and DII additions $(P<0.05$; Figure 4g). The PFe treatment also yielded elevated ${ }^{15} \mathrm{~N}$ that was nearly twice as high as the control values (Figure $4 \mathrm{~g}$ and Supplementary Table 1).
In comparison, ${ }^{15} \mathrm{~N}$ enrichment within haptophyte cells dropped significantly in the $\mathrm{N}$ treatment, as well as in the NPFe treatment $(P<0.05$; Figure $4 \mathrm{~g}$ and Supplementary Table 1). Corresponding $\mathrm{N}_{2}$-derived $\mathrm{N}$ transfer rates to haptophyte cells increased in all nutrient additions compared with the control experiment, except in treatments in which fixed $\mathrm{N}$ was added, where rates were not significantly different from the control (Table 1 and 
Figure 4h). The $\mathrm{N}_{2}$-derived $\mathrm{N}$ transfer rates to haptophyte cells were significantly enhanced in the Fe, Saharan dust DI and DII treatments relative to the control $(P<0.05$; Table 1 and Figure $4 \mathrm{~h})$. A high rate of $0.08 \mathrm{fmol} \mathrm{N}$ cell $^{-1} \mathrm{~h}^{-1}$ was also observed in the single haptophyte cell from the PFe treatment (about five times the rate of the control; Table 1 and Figure 4h). Overall, strong correlations in the ${ }^{15} \mathrm{~N}$ enrichment $(r=0.98)$ as well as in $\mathrm{N}_{2}$ fixation rates or transfer rates $(r=0.81)$ between UCYN-A and haptophyte cells were detected across all treatments (Figures 5c and d).

Table 1 Summary of nanoSIMS analysis for the UCYN-A-haptophyte association from nutrient incubation experiments conducted on surface seawater samples collected from Cape Verde in May 2009

\begin{tabular}{|c|c|c|c|c|c|}
\hline \multirow[t]{2}{*}{$\begin{array}{l}\text { Experiment } \\
\text { (treatment) }\end{array}$} & \multirow[t]{2}{*}{$N^{\mathrm{a}}$} & \multicolumn{2}{|c|}{$\begin{array}{c}\mathrm{CO}_{2} \text { fixation or } C \text { transfer rate }\left(\text { fmol } C \text { cell }^{-1} h^{-1}\right) \\
\text { Mean } \pm \text { s.d. }\end{array}$} & \multicolumn{2}{|c|}{$\begin{array}{c}N_{2} \text { fixation or } N \text { transfer rate }\left(\text { fmol } N \text { cell }^{-1} h^{-1}\right) \\
\text { Mean } \pm \text { s.d. }\end{array}$} \\
\hline & & $U C Y N-A$ & Haptophyte & $U C Y N-A$ & Haptophyte \\
\hline Ctr & 8 & $0.06 \pm 0.01$ & $0.32 \pm 0.04^{\mathrm{b}}$ & $0.0031 \pm 0.0005$ & $0.0158 \pm 0.0024$ \\
\hline $\mathrm{N}$ & 8 & $0.09 \pm 0.02$ & $0.56 \pm 0.07^{\mathrm{b}}$ & $0.0020 \pm 0.0007$ & $0.0127 \pm 0.0034$ \\
\hline $\mathrm{Fe}$ & 5 & $0.15 \pm 0.03^{\mathrm{b}}$ & $0.51 \pm 0.05^{\mathrm{b}}$ & $0.0072 \pm 0.0014^{\mathrm{b}}$ & $0.0326 \pm 0.0034^{\mathrm{b}}$ \\
\hline NP & 5 & $0.19 \pm 0.04^{\mathrm{b}}$ & $0.84 \pm 0.09^{\mathrm{b}}$ & $0.0062 \pm 0.0017$ & $0.0323 \pm 0.0089$ \\
\hline $\mathrm{NFe}$ & 4 & $0.09 \pm 0.03$ & $0.69 \pm 0.16^{\mathrm{b}}$ & $0.0041 \pm 0.0014$ & $0.0264 \pm 0.0088$ \\
\hline NPFe & 5 & $0.16 \pm 0.02^{\mathrm{b}}$ & $0.68 \pm 0.05^{\mathrm{b}}$ & $0.0044 \pm 0.0008$ & $0.0231 \pm 0.0018$ \\
\hline Pfe & 1 & $0.16^{\mathrm{c}}$ & $0.89^{\mathrm{c}}$ & $0.0115^{\mathrm{c}}$ & $0.0789^{\mathrm{c}}$ \\
\hline DI & 4 & $0.11 \pm 0.04$ & $0.62 \pm 0.02^{\mathrm{b}}$ & $0.0069 \pm 0.0021^{\mathrm{b}}$ & $0.0475 \pm 0.0023^{\mathrm{b}}$ \\
\hline DII & 4 & $0.13 \pm 0.04$ & $0.45 \pm 0.10$ & $0.0134 \pm 0.0042^{\mathrm{b}}$ & $0.0580 \pm 0.0144^{\mathrm{b}}$ \\
\hline
\end{tabular}

Abbreviations: Ctr, controls; nanoSIMS, nanometer scale secondary ion mass spectrometry.

The mean and s.d. are listed for $\mathrm{CO}_{2}$ and $\mathrm{N}_{2}$ fixation and transfer rates for individual UCYN-A and partner haptophyte cells.

${ }^{a}$ Number of cells measured in each treatment.

bSignificantly different from control measurements.

'Based on one UCYN-A-haptophyte symbiosis.
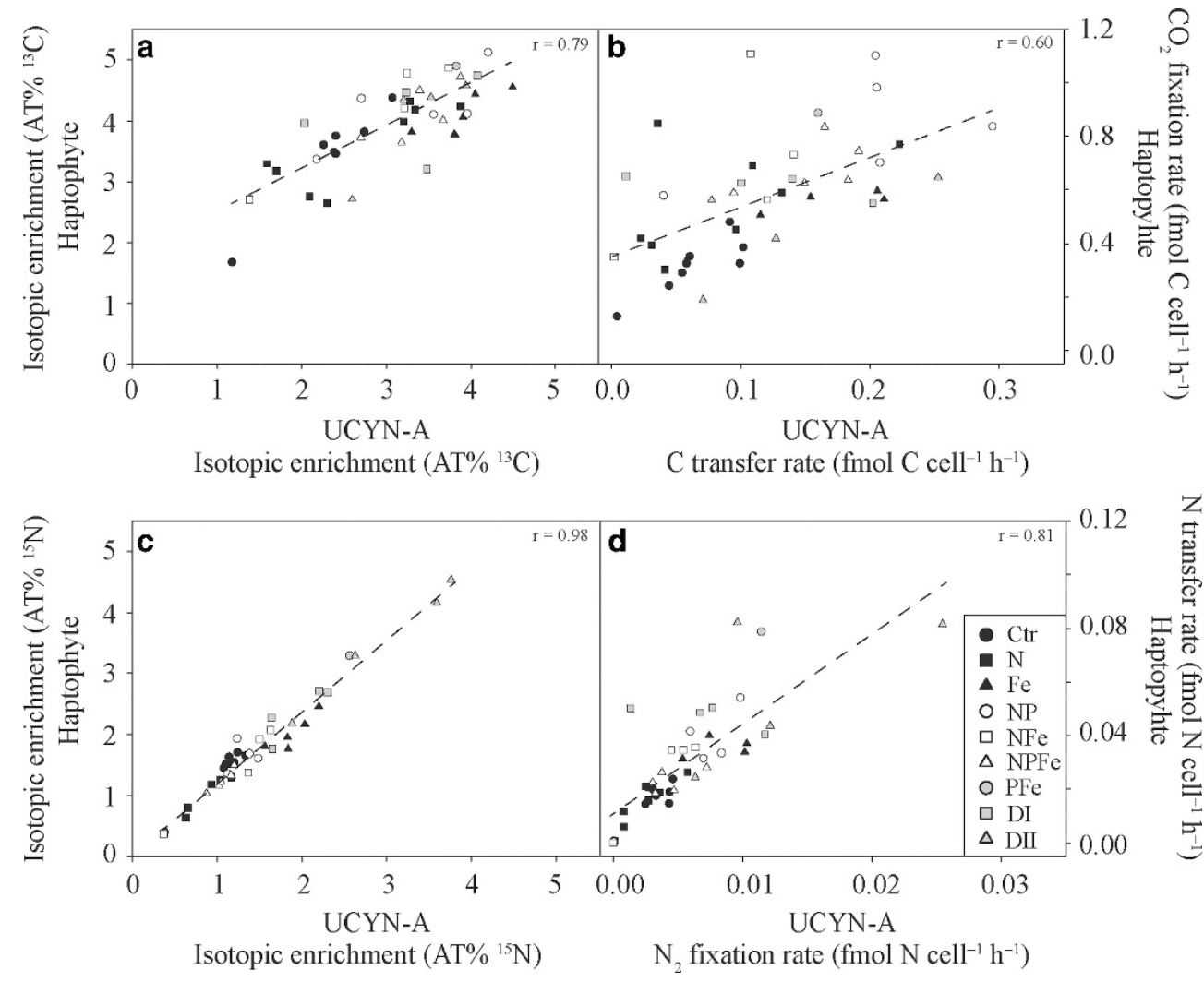

Figure 5 Single-cell enrichments and rates for (a, b) carbon in $\mathrm{AT} \%{ }^{13} \mathrm{C}$ and fmol $\mathrm{C} \mathrm{cell}^{-1} \mathrm{~h}^{-1}$, respectively, and for (c, d) nitrogen in AT\% ${ }^{15} \mathrm{~N}$ and fmol $\mathrm{N} \mathrm{cell}^{-1} \mathrm{~h}^{-1}$, respectively, within individual associations between UCYN-A and its corresponding haptophyte partner cell across all treatments. Dashed lines represent regression lines and their corresponding $r$-values are depicted within each panel. Treatments are as described in Materials and Methods. 
Unknown structures within the UCYN-A-haptophyte association

In incubations with $\mathrm{NH}_{4} \mathrm{NO}_{3}$, a third structure was observed in some UCYN-A-haptophyte associations $(n=6)$ (Figures 6a-f). Besides weak DAPI signals, these structures were found because of their distinct $\mathrm{C}$ isotopic signature revealed by nanoSIMS measurements. This enigmatic structure was slightly smaller than UCYN-A cells, with a diameter and s.d. of $0.70 \pm 0.06 \mu \mathrm{M}(n=6)$ and a volume of $0.21 \pm 0.06 \mu^{3}(n=6)$. These structures were highly enriched in ${ }^{13} \mathrm{C}\left(\mathrm{AT} \%{ }^{13} \mathrm{C} 5.16 \pm 0.44\right)$, but lower in ${ }^{15} \mathrm{~N}\left(\mathrm{AT} \%{ }^{15} \mathrm{~N} 0.54 \pm 0.06\right)$ compared with both UCYN-A and the haptophyte. On average, these structures were approximately twothirds more enriched in ${ }^{13} \mathrm{C}$ than UCYN-A cells and approximately one-third more than haptophyte cells. Furthermore, these structures were $\sim 2.5$ times less enriched in ${ }^{15} \mathrm{~N}$ than UCYN-A cells and 3 times less enriched than haptophyte cells across all treatments.

\section{Discussion}

The $\mathrm{N}_{2}$ fixation rates (bulk and single cell) reported here represent minimum fixation rates; the common ${ }^{15} \mathrm{~N}_{2}$ gas tracer addition method ('bubble method') was applied to the incubation experiments that has been shown to underestimate $\mathrm{N}_{2}$ fixation (Mohr et al., 2010a; Großkopf et al., 2012; Wilson et al., 2012). Given that the stable isotope addition experiments were initiated at the same time with the same initial microbial community from a common seawater sample, and treated with the same conditions except for the nutrient addition treatments, it is reasonable to assume that the 'bubble method' affected $\mathrm{N}_{2}$ fixation rates in all treatments in the same manner. Hence, the relative response of $\mathrm{N}_{2}$ fixation to the nutrient additions is comparable between treatments.

The open surface waters in the vicinity of Cape Verde are chronically depleted in macronutrients, particularly fixed $\mathrm{N}$ species, and are therefore
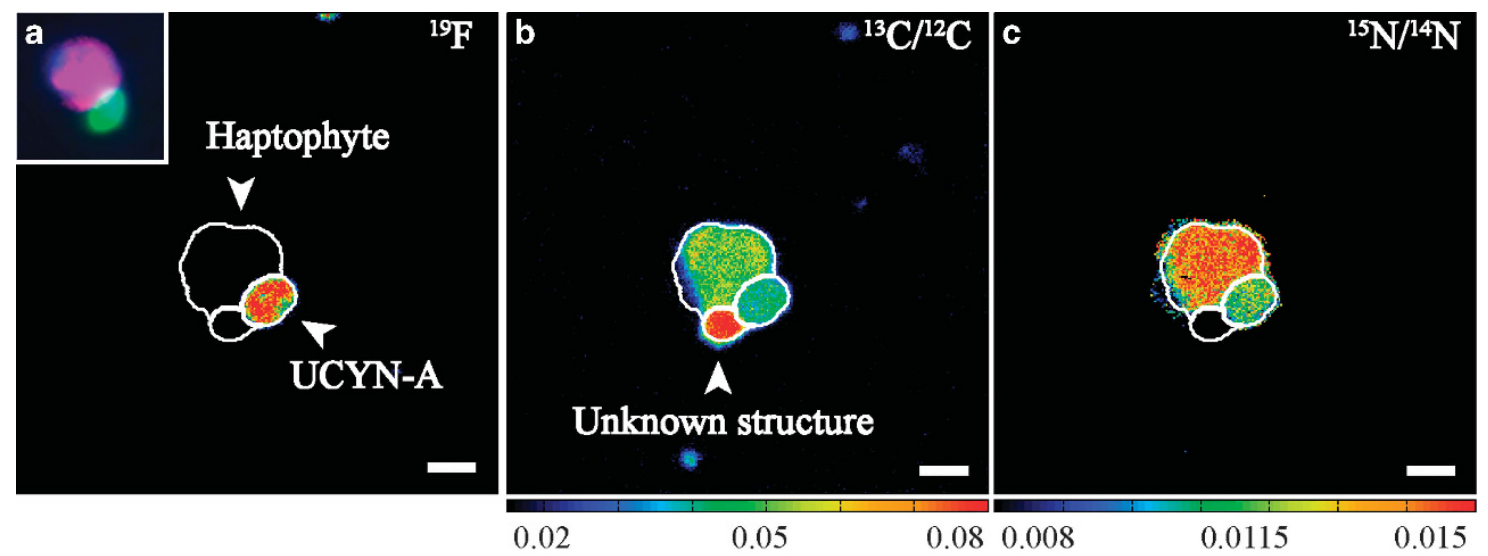

0.05

$0.08 \quad 0.008$

0.0115

0.015
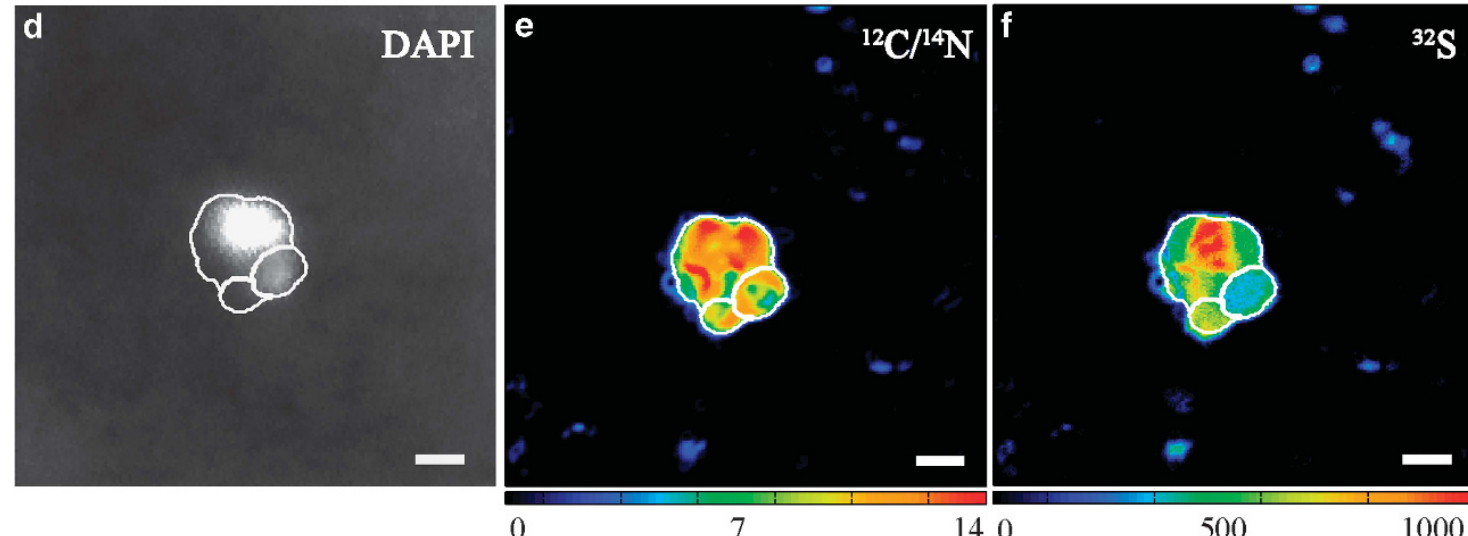

Figure 6 NanoSIMS measurements visualizing the 'unknown structure' found attached to a UCYN-A-haptophyte association within the NP treatment. (a) The probe-conferred ${ }^{19} \mathrm{~F}$ signal and the corresponding epifluorescence images of the UCYN-A cells (green signal) and its associated haptophyte cell (red signal), as well as DAPI staining (blue signal) based on double CARD-FISH approach taken before nanoSIMS analysis (small inset panel). (b) Carbon enrichment as ${ }^{13} \mathrm{C} /{ }^{12} \mathrm{C}$, (c) nitrogen enrichment as ${ }^{15} \mathrm{~N} /{ }^{14} \mathrm{~N}$, (d) black and white image of the DAPI signals, (e) carbon and nitrogen distribution as ${ }^{12} \mathrm{C} /{ }^{14} \mathrm{~N} * 1000$ and (f) sulfur as ${ }^{32} \mathrm{~S}$. An unknown structure attached to the UCYN-A association was observed that is highly enriched in C, but lower in N and had a weak DAPI signal (b, c, d). In addition to carbon and nitrogen (b, c, e) the structure contained sulfur (f). Such a structure was only found when inorganic nitrogen was added. Warmer colors represent higher abundance of the heavier isotopes. Brighter white DAPI signals indicate stronger staining because of more DNA. 
thought to favor the abundance and activity of $\mathrm{N}_{2}$-fixing microorganisms (Voss et al., 2004). Bulk $\mathrm{N}_{2}$ fixation rates were similar to rates previously reported from the subtropical North Atlantic (Mills et al., 2004; LaRoche and Breitbarth, 2005), as well as other oligotrophic sites (Falcón et al., 2004; Sohm et al., 2011; Luo et al., 2012). Across all nutrient treatments, bulk $\mathrm{N}_{2}$ fixation rates were neither significantly stimulated nor suppressed, suggesting that $\mathrm{N}_{2}$ fixation was neither limited by any of the added nutrients (or their combination) at this particular time nor inhibited in the presence of fixed N. However, it is also possible that the added nutrients affected bulk rates at timescales not considered here. As the bulk $\mathrm{N}_{2}$ fixation rates in this study represent community-wide responses, these results say little about nifH phylotype-specific responses. Turk-Kubo et al. (2012) recently found that changes in $\mathrm{N}_{2}$ fixation upon $\mathrm{Fe}$ and/or $\mathrm{P}$ addition were spatially heterogeneous in the tropical North Atlantic. They further reported that Fe and $\mathrm{P}$ additions caused varying responses among different phylotypes, suggesting that not all diazotrophs are limited by the same nutrient in time and space. For example, diazotrophs in the western tropical North Atlantic appeared to be Fe limited, whereas they were P limited in the eastern tropical North Atlantic. In particular, the uncultured cyanobacterial group A (UCYN-A; Thompson et al., 2012) responded to additions of $\mathrm{P}$ with increased nifH gene expression, indicating $\mathrm{P}$ limitation of diazotrophs despite the lack of a measurable response in bulk $\mathrm{N}_{2}$ fixation rates (Turk-Kubo et al., 2012). Here, we determined UCYN-A gene expression patterns upon nutrient additions including $\mathrm{N}, \mathrm{Fe}, \mathrm{P}$ and Saharan dust. In contrast to Turk-Kubo et al. (2012), there were no significant responses in nifH gene expression to any of the added nutrients (alone or in combination). This might be partially because of the larger variation in the transcript abundance seen in this study. Although all RNA samples were taken within a 3-h time window, diel cycling of nifH gene expression could be responsible for this variation. For example, nifH transcript abundance can change by more than one order of magnitude within $3 \mathrm{~h}$ in Crocosphaera watsonii (Mohr et al., 2010b). For UCYN-A, both diel (Church et al., 2005b; Zehr et al., 2008) and non-diel (Turk-Kubo et al., 2012) expressions of nifH have been found, and these findings suggest that nifH expression in UCYN-A is not yet fully understood.

The UCYN-A have been found to live in association with a phototrophic eukaryote, more specifically a haptophyte (Thompson et al., 2012; Hagino et al., 2013; Krupke et al., 2013, 2014). A symbiotic lifestyle originally had been suggested because of the reduced genome size and in particular the absence of several genes required for carbon fixation in UCYN-A (Zehr et al., 2008; Tripp et al., 2010). It was shown that the two partners in this symbiotic association, that is, the haptophyte and UCYN-A, exchange $\mathrm{C}$ and $\mathrm{N}$ compounds; the haptophyte supplies $\mathrm{CO}_{2}$-derived $\mathrm{C}$ and UCYN-A supplies $\mathrm{N}_{2}$ derived N (Thompson et al., 2012; Krupke et al., 2013). This symbiotic association raises questions about its nutrient requirements and the interdependence of the two partner organisms, especially given that phytoplankton are usually affected by $\mathrm{N}$ limitation, whereas diazotrophs are considered limited by either P, Fe or both in the eastern tropical Atlantic. In order to address the question of nutrient limitation, we evaluated single-cell $\mathrm{N}_{2}$ and $\mathrm{CO}_{2}$ fixation activities by the UCYN-A-haptophyte association under different nutrient additions. The response of UCYN-A to the different nutrient treatments was unexpected given the fact that bulk $\mathrm{N}_{2}$ fixation rates showed no clear response and that there were no significant changes in the nifH expression. We found that $\mathrm{N}_{2}$ fixation by UCYN-A was clearly stimulated by the addition of Saharan dust. In addition, UCYN-A activity was also stimulated by the addition of $\mathrm{Fe}$, suggesting that the Saharan dust served as a source of Fe. An increase in UCYN-A abundance in response to dust has been observed in a comparable experiment in the Atlantic, although the authors did not see a change in abundance in their $\mathrm{Fe}$ treatment (Langlois et al., 2012). The deposition of dust in the marine environment may also release $\mathrm{P}$ in addition to $\mathrm{Fe}$ (Ridame and Guieu, 2002; Bonnet and Guieu, 2004). We could not determine the effect of $\mathrm{P}$ alone on the $\mathrm{N}_{2}$ fixation rates by UCYN-A because of the lack of associations in that treatment, but our results from the PFe treatment indicated elevated $\mathrm{N}_{2}$ fixation by UCYN-A relative to the control. However, these results have to be interpreted with caution because only one symbiosis was detected in that treatment. The combined results, however, suggest that UCYNA were Fe limited with a possible $\mathrm{Fe}$ and $\mathrm{P}$ colimitation, and that UCYN-A had the capability to utilize Saharan dust as a significant source of Fe and possibly other elements too.

The haptophyte partner responded to all nutrient additions with increased $\mathrm{CO}_{2}$ fixation, including treatments that contained no added N. This finding contradicts classical observations of $\mathrm{N}$ limitation in phytoplankton; however, in all treatments without added fixed $\mathrm{N}$, the haptophyte received significant amounts of $\mathrm{N}$ from their UCYN-A partner cell, indicating that $\mathrm{N}_{2}$ fixation in UCYN-A and the subsequent transfer of $\mathrm{N}_{2}$-derived $\mathrm{N}$ is an important source for the haptophyte. It further implies that the increase in $\mathrm{CO}_{2}$ fixation by the haptophyte in treatments without added $\mathrm{N}$ is likely an indirect result of the positive effect of $\mathrm{Fe}$ and/or P on UCYNA $\mathrm{N}_{2}$ fixation and suggests that the haptophytes were $\mathrm{N}$ limited at the time of our study. In treatments where fixed $\mathrm{N}$ was added in combination with $\mathrm{Fe}$ or $\mathrm{P}$ (or both), the haptophyte could have either switched between the added $\mathrm{N}$ and the $\mathrm{N}_{2}$-derived $\mathrm{N}$ from UCYN-A or used both sources simultaneously. Under typical oligotrophic conditions, 
however, $\mathrm{N}_{2}$ fixation by UCYN-A is likely to be the main source of fixed $\mathrm{N}$ for the haptophyte, fuelled by the atmospheric deposition of Fe through dust at this study site.

The strong correlation between the ${ }^{15} \mathrm{~N}$ isotope enrichment in the haptophyte and the ${ }^{15} \mathrm{~N}$ isotope enrichment in UCYN-A (and the similarly strong correlation between the ${ }^{13} \mathrm{C}$ isotope enrichments in both organisms) indicates a mutually beneficial relationship and a significant degree of dependence of both organisms on each other. On average, UCYNA cells assimilated $16.4 \pm 7.1 \%$ of all $\mathrm{C}$ fixed by the haptophyte and the haptophyte cells assimilated $85.4 \pm 5.1 \%$ of $\mathrm{N}$ fixed by UCYN-A. These values are similar to recent findings that show UCYN-A transferring up to $95 \%$ of its fixed $\mathrm{N}$ to the host, and in turn receiving $\sim 17 \%$ of the $\mathrm{C}$ fixed from the host (Thompson et al., 2012). A similar transfer of C and $\mathrm{N}$ has also been reported for symbiotic relationships between diatoms and $\mathrm{N}_{2}$-fixing cyanobacteria (diazotroph-diatom symbiotic associations) (Foster et al., 2011). Similar to our study, other field studies have shown that fixed $\mathrm{N}$ is rapidly transferred (that is, $\leq 24 \mathrm{~h}$ ), for example, from heterocysts to vegetative cells in Aphanizomenon sp. populations (Ploug et al., 2010), as well as within diazotroph-diatom symbiotic associations (Foster et al., 2011). These results indicate an efficient nutrient transfer between the two partner cells. However, the exact mechanisms that allow for rapid nutrient exchange and the type of compounds that are exchanged remain unknown. Interestingly, the increase in $\mathrm{CO}_{2}$ fixation triggered by fixed inorganic $\mathrm{N}$ addition alone did not result in an increased transfer of $\mathrm{CO}_{2}$ derived C to UCYN-A or to an increased transfer of $\mathrm{N}_{2}$-derived $\mathrm{N}$ from UCYN-A to the haptophyte. Combined, these results suggest that a simple increase in primary productivity (possibly triggered by an external source of fixed $\mathrm{N}$ ) does not automatically result in elevated $\mathrm{C}$ transfer to the symbiont, but that any $\mathrm{C}$ transfer is coupled to transfer of $\mathrm{N}$ from UCYN-A to the haptophyte. The strong correlations of $\mathrm{C}$ and $\mathrm{N}$ enrichments between both organisms under changing nutrient regimes imply that the transfer of $\mathrm{C}$ and/or $\mathrm{N}$ between host and symbiont is concomitant and highly regulated. This tight coupling in $\mathrm{C}$ and $\mathrm{N}$ metabolism stays balanced even under changing nutrient regimes and indicates that the association between UCYN-A and the haptophyte is an 'obligate' symbiosis (Krupke et al., 2014; Thompson et al., 2014).

Interestingly, we did not observe an inhibition of UCYN-A nifH expression and $\mathrm{N}_{2}$ fixation when fixed $\mathrm{N}$ was added as ammonium nitrate. However, other organisms in the incubations (for example, other phytoplankton) might have rapidly taken up the added fixed $\mathrm{N}$, preventing an inhibition of nifH expression or resulting in temporary inhibition of nifH expression only. Thus, inhibitory effects in nifH gene expression may have been missed at the end of the incubation time. Other cultivated members of the UCYN groups have also been shown to be nonresponsive to additions of nitrate (Dekaezemacker and Bonnet, 2011; Großkopf and LaRoche, 2012), and as the understanding of the UCYN-A physiology is in its early stages, it is possible that $\mathrm{N}_{2}$ fixation in UCYN-A is not inhibited in the presence of fixed $\mathrm{N}$.

We observed an unknown structure within the UCYN-A-haptophyte association that occurred in treatments that had ammonium nitrate additions. Presently, it is unclear what this structure might represent: it could be a C-storage compartment, for example carbohydrates. This structure may also be an attached unidentified microorganism as it contains $\mathrm{C}, \mathrm{N}$ and sulfur (S), and a weak DAPI signal was observed. Diffuse or very weak DAPI signals are common for small cells. Because this structure is more enriched in ${ }^{13} \mathrm{C}$ than the photosynthetic partner algae of UCYN-A, it may be an unidentified photosynthetic or chemolithoautotrophic organism. Symbiotic relationships between marine diatoms and multiple unicellular $\mathrm{N}_{2}$-fixing cyanobacterial endosymbionts have been reported previously (Villareal, 1991; Carpenter and Janson, 2000). Here, photosynthetic activity can be restricted to the algal partner cell that supplies the other partners with fixed C compounds. Similar observations have been made in tripartite symbiotic relationships between fungi, algae and cyanobacteria (Honegger, 2001). Flexibility of the epibiont load (potential tripartite symbiosis) might offer competitive growth advantages for the haptophyte and/or UCYN-A under varying nutrient environments. The identification of a possible third partner cell will be an important step in understanding the complex interactions in this symbiosis.

\section{Concluding remarks}

This study provides the first insight into the physiological responses of field populations of the UCYN-A-haptophyte symbiosis to nutrient addition. Our results suggest that the presence of fixed $\mathrm{N}$ does not necessarily inhibit $\mathrm{N}_{2}$ fixation and highlight that $\mathrm{Fe}$ (including $\mathrm{Fe}$ from Saharan dust deposition) and $\mathrm{P}$ inputs are major factors influencing $\mathrm{N}_{2}$ fixation activity by UCYN-A. The subsequent transfer of fixed $\mathrm{N}$ to the photosynthetic partner haptophyte indirectly fuels primary productivity. The discovery of a third microstructure within the UCYN-A-haptophyte association, possibly an unknown cell, emphasizes the complexity of interactions among microorganisms in oligotrophic surface waters. Future efforts to gather genetic information on the metabolic repertoire of the associated haptophyte will help to unravel mechanisms and potential pathways regulating the $\mathrm{C}$ and $\mathrm{N}$ exchange within this association and may provide critical information for future isolation attempts of both partner cells. Here, we provide evidence for a tight coupling of $\mathrm{C}$ and $\mathrm{N}$ exchange within this 
symbiosis in the Atlantic Ocean that may represent a different ecotype (Thompson et al., 2014) than previously reported (Thompson et al., 2012). The determined metabolic activities, cell diameters and biovolumes of the two partner cells will be helpful to deepen our understanding of their roles in the global $\mathrm{C}$ and $\mathrm{N}$ cycles.

\section{Conflict of Interest}

The authors declare no conflict of interest.

\section{Acknowledgements}

We thank the captain and crew of the R/V Islandia and the staff of the Instituto Nacional de Desenvolvimento das Pescas (INDP), Cape Verde, for their hospitality and assistance. We also thank Timothy G Ferdelman and Sara J Bender for manuscript feedback. We thank Surface Ocean Processes in the Anthropocene (Sopran) and the Sonderforschungsbereich SFB754 for financial support. This study was funded by the Max Planck Society. AK was a member of the International Max Planck Research School of Marine Microbiology (MarMic).

\section{References}

Amann RI, Binder BJ, Olson RJ, Chisholm SW, Devereux R, Stahl DA. (1990). Combination of 16S Rrna-targeted oligonucleotide probes with flow cytometry for analyzing mixed microbial populations. Appl Environ Microbiol 56: 1919-1925.

Bonnet S, Guieu C. (2004). Dissolution of atmospheric iron in seawater. Geophys Res Lett 31: 1-4.

Capone DG, Burns JA, Montoya JP, Subramaniam A, Mahaffey C, Gunderson T et al. (2005). Nitrogen fixation by Trichodesmium spp.: an important source of new nitrogen to the tropical and subtropical North Atlantic Ocean. Glob Biogeochem Cycles 19: 1-17.

Carpenter EJ, Foster RA. (2003). Marine cyanobacterial symbioses. In: Rai AN, Bergman B, Rasmussen U (eds) Cyanobacteria in Symbiosis. Kluwer Academic Publishers: Dordrecht, the Netherlands, pp 11-17.

Carpenter EJ, Janson S. (2000). Intracellular cyanobacterial symbionts in the marine diatom Climacodium frauenfeldianum (Bacillariophyceae). J Phycol 36: 540-544.

Church MJ, Jenkins BD, Karl DM, Zehr JP. (2005a). Vertical distributions of nitrogen-fixing phylotypes at stn ALOHA in the oligotrophic North Pacific Ocean. Aquat Microb Ecol 38: 3-14.

Church MJ, Short CM, Jenkins BD, Karl DM, Zehr JP. (2005b). Temporal patterns of nitrogenase gene ( if $H$ ) expression in the oligotrophic North Pacific Ocean. Appl Environ Microbiol 71: 5362-5370.

Dekaezemacker J, Bonnet S. (2011). Sensitivity of $\mathrm{N}_{2}$ fixation to combined nitrogen forms $\left(\mathrm{NO}_{3}^{-}\right.$and $\left.\mathrm{NH}_{4}^{+}\right)$ in two strains of the marine diazotroph Crocosphaera watsonii (Cyanobacteria). Mar Ecol Prog Ser 438: 33-46.

Falcón LI, Carpenter EJ, Cipriano F, Bergman B, Capone DG. (2004). $\mathrm{N}_{2}$ fixation by unicellular bacterioplankton from the Atlantic and Pacific Oceans: phylogeny and in situ rates. Appl Environ Microbiol 70: 765-770.
Foster RA, Kuypers MMM, Vagner T, Paerl RW, Musat N, Zehr JP. (2011). Nitrogen fixation and transfer in open ocean diatom-cyanobacterial symbioses. ISME $J$ 5: 1484-1493.

Großkopf T, LaRoche J. (2012). Direct and indirect costs of dinitrogen fixation in Crocosphaera watsonii WH8501 and possible implications for the nitrogen cycle. Front Aquat Microbiol 3: 1-10.

Großkopf T, Mohr W, Baustian T, Schunck H, Gill D, Kuypers MMM et al. (2012). Doubling of marine dinitrogen-fixation rates based on direct measurements. Nature 488: 361-364.

Hagino K, Onuma R, Kawachi M, Horiguchi T. (2013). Discovery of an endosymbiotic nitrogen-fixing cyanobacterium UCYN-A in Braarudosphaera bigelowii (prymnesiophyceae). PLoS One 8: e81749.

Heller M, Croot P. (2011). Superoxide decay as a probe for speciation changes during dust dissolution in Tropical Atlantic surface waters near Cape Verde. Mar Chem 126: $37-55$.

Honegger R. (2001). The symbiotic phenotype of lichenforming ascomycetes. In Hock (ed), Fungal Associations. Springer-Verlag: Berlin, Heidelberg, pp 165-188.

Karl D, Michaels A, Bergman B, Capone D, Carpenter E, Letelier $\mathrm{R}$ et al. (2002). Dinitrogen fixation in the world's oceans. Biogeochemistry 57: 47-98.

Karl DM, Church MJ, Dore JE, Letelier RM, Mahaffey C. (2012). Predictable and efficient carbon sequestration in the North Pacific Ocean supported by symbiotic nitrogen fixation. Proc Natl Acad Sci USA 109: 1842-1849.

Krupke A, Lavik G, Halm H, Fuchs BM, Amann RI, Kuypers MM. (2014). Distribution of a consortium between unicellular algae and the N2 fixing cyanobacterium UCYN-A in the North Atlantic Ocean. Environ Microbiol 16: 3153-3167.

Krupke A, Musat N, LaRoche J, Mohr W, Fuchs BM, Amann RI et al. (2013). In situ identification and $\mathrm{N}_{2}$ and $\mathrm{C}$ fixation rates of uncultivated cyanobacteria populations. Syst Appl Microbiol 36: 259-271.

Langlois R, Mills MM, Ridame C, Croot P, LaRoche J. (2012). Diazotrophic bacteria respond to Saharan dust additions. Mar Ecol Prog Ser 470: 1-14.

Langlois RJ, Hummer D, LaRoche J. (2008). Abundances and distributions of the dominant nifH phylotypes in the Northern Atlantic Ocean. Appl Environ Microbiol 74: 1922-1931.

LaRoche J, Breitbarth E. (2005). Importance of the diazotrophs as a source of new nitrogen in the ocean. J Sea Res 53: 67-91.

Luo YW, Doney SC, Anderson LA, Benavides M, Bode A, Bonnet $S$ et al. (2012). Database of diazotrophs in global ocean: abundances, biomass and nitrogen fixation rates. Earth Syst Sci Data 5: 47-106.

Mills MM, Ridame C, Davey M, La Roche J, Geider RJ. (2004). Iron and phosphorus co-limit nitrogen fixation in the eastern tropical North Atlantic. Nature 429: 292-294.

Mohr W, Großkopf T, Wallace DWR, LaRoche J. (2010a). Methodological underestimation of oceanic nitrogen fixation rates. PLoS One 5: e12583.

Mohr W, Intermaggio MP, LaRoche J. (2010b). Diel rhythm of nitrogen and carbon metabolism in the unicellular, diazotrophic cyanobacterium Crocosphaera watsonii WH8501. Environ Microbiol 12: 412-421.

Moisander PH, Beinart RA, Hewson I, White AE, Johnson KS, Carlson CA et al. (2010). Unicellular cyanobacterial 
distributions broaden the oceanic $\mathrm{N}_{2}$ fixation domain. Science 327: 1512-1514.

Montoya JP, Holl CM, Zehr JP, Hansen A, Villareal TA, Capone DG. (2004). High rates of $\mathrm{N}_{2}$ fixation by unicellular diazotrophs in the oligotrophic Pacific Ocean. Nature 430: 1027-1032.

Montoya JP, Voss M, Kahler P, Capone DG. (1996). A simple, high-precision, high-sensitivity tracer assay for $\mathrm{N}_{2}$-fixation. Appl Environ Microbiol 62: 986-993.

Musat N, Stryhanyuk H, Bombach P, Adrian L, Audinot J-N, Richnow HH. (2014). The effect of FISH and CARD-FISH on the isotopic composition of ${ }^{13} \mathrm{C}$ and ${ }^{15} \mathrm{~N}$-labeled Pseudomonas putida cells measured by nanoSIMS. Syst Appl Microbiol 37: 267-276.

Pernthaler A, Amann R. (2004). Simultaneous fluorescence in situ hybridization of mRNA and rRNA in environmental bacteria. Appl Environ Microbiol 70: 5426-5433.

Pernthaler A, Pernthaler J, Amann R. (2004). Sensitive multi-color fluorescence in situ hybridization for the identification of environmental microorganisms. Mol Microb Ecol Man 3: 711-726.

Ploug H, Musat N, Adam B, Moraru CL, Lavik G, Vagner T et al. (2010). Carbon and nitrogen fluxes associated with the cyanobacterium Aphanizomenon sp. in the Baltic Sea. ISME J 4: 1215-1223.

Polerecky L, Adam B, Milucka J, Musat N, Vagner T, Kuypers MMM. (2012). Look@NanoSIMS-a tool for the analysis of nanoSIMS data in environmental microbiology. Environ Microbiol 4: 1009-1023.

Rees AP, Gilbert JA, Kelly - Gerreyn BA. (2009). Nitrogen fixation in the western English Channel (NE Atlantic ocean). Mar Ecol Prog Ser 374: 7-12.

Ridame C, Guieu C. (2002). Saharan input of phosphate to the oligotrophic water of the open western Mediterranean Sea. Limnol Oceanogr 47: 856-869.

Sañudo-Wilhelmy SA, Kustka AB, Gobler CJ, Hutchins DA, Yang M, Lwiza K et al. (2001). Phosphorus limitation of nitrogen fixation by Trichodesmium in the central Atlantic Ocean. Nature 411: 66-69.

Shi T, Sun Y, Falkowski PG. (2007). Effects of iron limitation on the expression of metabolic genes in the marine cyanobacterium Trichodesmium erythraeum IMS101. Environ Microbiol 9: 2945-2956.

Short SM, Zehr JP. (2007). Nitrogenase gene expression in the Chesapeake Bay Estuary. Environ Microbiol 9: 1591-1596.

Simon N, Campbell L, Örnólfsdóttir E, Groben R, Guillou L, Lange $\mathrm{M}$ et al. (2000). Oligonucleotide probes for the identification of three algal groups by dot blot and fluorescent whole-cell hybridization. J Eukaryot Microbiol 47: 76-84.

Sohm JA, Webb EA, Capone DG. (2011). Emerging patterns of marine nitrogen fixation. Nat Rev Microbiol 9: 499-508.

Strathmann RR. (1967). Estimating the organic carbon content of phytoplankton from cell volume or plasma volume. Limnol Oceanogr 12: 411-418.
Thompson A, Carter BJ, Turk-Kubo K, Malfatti F, Azam F, Zehr JP. (2014). Genetic diversity of the unicellular nitrogen-fixing cyanobacteria UCYN-A and its prymnesiophyte host. Environ Microbiol 16: 3238-3249.

Thompson AW, Foster RA, Krupke A, Carter BJ, Musat N, Vaulot D et al. (2012). Unicellular cyanobacterium symbiotic with a single-celled eukaryotic alga. Science 337: 1546-1550.

Tripp HJ, Bench SR, Turk KA, Foster RA, Desany BA, Niazi $\mathrm{F}$ et al. (2010). Metabolic streamlining in an open-ocean nitrogen-fixing cyanobacterium. Nature 464: 90-94.

Tuit C, Waterbury J, Ravizza G. (2004). Diel variation of molybdenum and iron in marine diazotrophic cyanobacteria. Limnol Oceanogr 49: 978-990.

Turk-Kubo KA, Achilles KM, Serros TR, Ochiai M, Montoya JP, Zehr JP. (2012). Nitrogenase (nifH) gene expression in diazotrophic cyanobacteria in the Tropical North Atlantic in response to nutrient amendments. Front Aquat Microbiol 3: 386.

Verity PG, Robertson CY, Tronzo CR, Andrews MG, Nelson JR, Sieracki ME. (1992). Relationships between cell volume and the carbon and nitrogen content of marine photosynthetic nanoplankton. Limnol Oceanogr 37: 1434-1446.

Villareal TA. (1991). Nitrogen-fixation by the cyanobacterial symbiont of the diatom genus Hemiaulus. Mar Ecol Prog Ser 76: 201-204.

Voss M, Croot P, Lochte K, Mills M, Peeken I. (2004). Patterns of nitrogen fixation along $10{ }^{\circ} \mathrm{N}$ in the tropical Atlantic. Geophys Res Lett 31: 1-4.

Wallner G, Amann R, Beisker W. (1993). Optimizing fluorescent in situ hybridization with rRNA targeted oligonucleotide probes for flow cytometric identification of microorganisms. Cytometry 14: 136-143.

Wilson ST, Böttjer D, Church MJ, Karl DM. (2012). Comparative assessment of nitrogen fixation methodologies conductedin the oligotrophic North Pacific Ocean. Appl Environ Microbiol 78: 6516-6523.

Zani S, Mellon MT, Collier JL, Zehr JP. (2000). Expression of nifH genes in natural microbial assemblages in Lake George, New York, detected by reverse transcriptase PCR. Appl Environ Microbiol 66: 3119-3124.

Zehr JP, Bench SR, Carter BJ, Hewson I, Niazi F, Shi T et al. (2008). Globally distributed uncultivated oceanic $\mathrm{N}_{2}$-fixing cyanobacteria lack oxygenic photosystem II. Science 322: 1110-1112.

Zehr JP, McReynolds LA. (1989). Use of degenerate oligonucleotides for amplification of the nifH gene from the marine cyanobacterium Trichodesmium thiebautii. Appl Environ Microbiol 55: 2522-2526.

Zehr JP, Mellon MT, Zani S. (1998). New nitrogen-fixing microorganisms detected in oligotrophic oceans by amplification of nitrogenase (nifH) genes. Appl Environ Microbiol 64: 3444-3450.

Zehr JP, Waterbury JB, Turner PJ, Montoya JP, Omoregie E, Steward GF et al. (2001). Unicellular cyanobacteria fix $\mathrm{N}_{2}$ in the subtropical North Pacific Ocean. Nature 412: 635-637.

Supplementary Information accompanies this paper on The ISME Journal website (http://www.nature.com/ismej) 